\title{
PRINCIPAL'S ORGANIZATIONAL MANAGEMENT AND THE IMPLEMENTATION OF ISLAMIC VALUE: A CASE STUDY IN SMP AL-AZHAR MANDIRI PALU
}

\author{
Mohamad Syafri ${ }^{1}$ \\ ${ }^{15}$ SPI, Fak. Ushuluddin Adab dan Dakwah, IAIN Palu, Palu, syafri@iainpalu.ac.id
}

\begin{abstract}
The purpose of the study is to picture the role of school principal's organizational management in implementing organizational communication and reward done in Al-Azhar Mandiri Palu Junior High School. The research also enpicture how school's management could lead to beneficial effect, including the implementation of Islamic value. The method used in this research is qualitative method with in-depth interview, documentation, and observation as the instruments. The research was analyzed using data reduction, presentation, and verification. (1) The research showed that interpersonal communication is the main pilar in building the communication, those are supported with the use of communication technology and social networking efficiently and effectively. (2) The reward given to members of Al-Azhar Mandiri Palu are in form of intrinsic and extrinsic. (3) Despite the school's status as a non-Islamic private school, but the school able to implement the Islamic value both for school's members and activities. It also lead to some achievement in Islamic field.
\end{abstract}

Keywords: Principal, Organizational Communication, Reward

\begin{abstract}
Abstrak. Tujuan dari penelitian ini adalah untuk memberikan gambaran mengenai peran kepala sekolah dalam menjalankan pengelolaan organisasi sekolah dalam bentuk pola komunikasi organisasi dan pemberian apresiasi di SMP Al-Azhar Mandiri Palu. Penelitian ini juga melihat bagaimana pola manajemen dapat menghasilkan penerapan nilai-nilai keislaman. Metode yang digunakan dalam penelitian ini adalah metode kualitatif dengan menggunakan wawancara mendalam, dokumen, dan observasi sebagai instrumennya. Penelitian ini melakukan analisa dnegan menggunakan reduksi data, presentasi, dan verifikasi. (1) penelitian menunjukkan bahwa komunikasi interpersonal adalah pilar utama dalam membangun komunikasi, hal tersebut ditunjang pula oleh penggunaan teknologi komunikasi dan jaringan sosial secara efisien dan efektif. (2) Pemberian apresiasi kepada para civitas SMP Al-Azhar Mandiri Palu dilakukan baik secara intrinsik maupun ekstrinsik. (3) Meskipun status sekolah adalaha sekolah swasta non-agama, akan tetapi nilai-nilai keislaman dapat terimplementasi secara baik kepada
\end{abstract}


civitas akademika dan kegiatan-kegiatan. Bahkan menghasilkan pencapaian gemilang pada bidang keislaman.

Kata kunci: Kepala Sekolah, Komunikasi Organisasi, Apresiasi

\section{Introduction}

In school's environment, principal holds the highest authority in running the school. Principal be the most responsible figure in term of how the learning activity, school administration, the development of educator and education staff, the managing and maintenance of teaching and learning facilities. ${ }^{1}$ In order to maximize and improving those elements, a proper understanding of managerial is necessary to be had by the school's principal. As the leader of the school, principal needs to be the main locomotive or motor the lead all the members of the school; teachers, staffs, students, and even parents. The success of a school is not possible to be achieved by one person as it is not a one-man show, the cooperation from all elements is a prerequisite factor.

The principal's ability to make all school's members to work together in order to achieve the school's goals is a prominent ability to be had by the principal as the head in school management. The indicator of good management ability by the principal is shown by the ability to make people work together to achieve the goals. ${ }^{2}$ Value is the prerequisite factor to be had by a school in order to run the system and achieve the goals. Doing a managerial working while keep on the track based on the value of the school is not an easy job, in fact schools commonly face troubles in doing those things.

Al-Azhar Mandiri Palu Junior High School or commonly known as SMP AlAzhar Mandiri Palu is one of the schools which able in holding their values and implementing good managerial. As the results, the school able to have brand awareness to the parents and also achieve prestigious achievements from local to international level. What they have achieve today is not an instant and simple job, started from 1992 when they begun their long-lasting and continual process to success. The main figure behind the success is the foundingfather and also the principal of SMP Al-Azhar Mandiri Palu, Drs. Abdul Basit Arsyad or commonly called as Mr. Basit. As a private school, Mr. Basit has been leading Al-Azhar Mandiri Palu for more than two decades. Experiences and continual efforts is the two keys of SMP Al-Azhar Mandiri Palu.

The efforts require the ability of the principal to keep the innovations and management ability. The main core of innovations and management ability is the school's organizational communication and a proper reward as appreciation,

${ }^{1}$ Syarwani Ahmad, "Faktor Penentu Keberhasilan Kepala Sekolah," Jurnal Penelitian dan Evaluasi Pendidikan 17, No. 1 (2013): 127-147.

2 Ibid 
especially in the condition where time moves faster. Both the organizational communication and rewarding effectively are some of the main points in $\mathrm{Mr}$. Basit's leadership.

Therefore, this research as a qualitative research focuses on how the principal leadership of SMP Al-Azhar Mandiri Palu seen from the two indicators; organizational communication and rewarding. Also this research highlighted how the consistency of good managerial able to one of the leading factors in implementation of Islamic value. Clasified as case study, the sources of data is taken from the headmasters, teachers, and students of SMP Al-Azhar Mandiri Palu using in-depthe intervie, observation, and documentation as the data collecting technique. In order to have a reliable result, data triangualation was conducted.

\section{Principal}

As an educational institution, school also depends on managerial system. The school itself is a complex interrelated system that consist of principal, teachers, curriculum, teaching materials, facilities, financial support, parents, and environment. ${ }^{3}$ Among all there should be a motor which is known as principal. The principal is the one that could lead the school to be an effective, provide good quality, and be a favorite school. ${ }^{4}$

Related with its important role, strong and visionary leadership for principal is needed. The principal has prominent role, according to the Government Ordinance No 28, year 1990, article 12 section 1, principal is obliged to run and conduct school activity, school administration, to regulate other educational staff and manage the use and maintenance of school's facility. ${ }^{5}$ The law then explained by the Ministry of Education, there are 5 main things that become the principal's job, those are;

1. Making and or perfecting vision, mission, and school's goals.

2. Organizing school's organization.

3. Plan School's Mid-Term Planning and Yearly Term Planning.

4. Regulate school's rules.

5. And improving school's information system. ${ }^{6}$

As can be seen above, the principal has great responsibility in the school management. However, despite all of the jobs that should be done by the principal, its is should be known that principal is a person. The idea of principal

${ }^{3}$ Kodiran, "Kepala Sekolah Sebagai Tugas Tambahan," Al-Idarah: Jurnal Kependidikan Islam. 8, No. 1 (2017): 146-158.

${ }^{4}$ Muhammad Sholeh, "Kefektifan Peran Kepala Sekolah dalam Meningkatkan Kinerja Guru," Jurnal Dinamika Manajemen Pendidikan. 1, No. 1 (2016): 41-54

${ }^{5}$ Indonesia Government Ordinance No 28 y. 1990, art. 12, sec. 1

${ }^{6}$ Ministry of Education and Culture, 2017, Panduan Kerja Kepala Sekolah, Jakarta. 
is to lead not to work. The principal's roles are manager, leader, administrator, and supervisor. ${ }^{7}$ The prominent role that is played by the principal is to ensure that every people and resources can be managed properly. Based on this grand idea about school's principal, it can be stated clearly that principal need to manage all the people and resources in order to achieve the school's goals.

School's principal stands in grand idea of leading. Leading is not simple matter, to be able to be called as leader people should have the ability to lead people to move together into the set goals. ${ }^{8}$ Strengthen by Kodiran, that the principal is a Manager Type Human Resources dan synchronize and managing the Executor Type Human Resources. ${ }^{9}$ Their role should not be taken lightly and also should be prioritize in term of improving their quality. As to make their strategic role effective is a real act of improving the quality of education itself. ${ }^{10}$

In term of to play their role as efficient as possible, the principal need to be pictured as the role model. Following this idea, the government itself has set high standard of principal. There are at least five requirements for principal, excluding the administrative requirements, as explained in The Minister of Education Ordinance No 13, Year 2007, those are personality, managerial, entrepreneurship, supervision, and social competences. The principal's function also including to maintain the relationship between the school and society. ${ }^{11}$ Therefore, the principal need to be able to portrayed himself as a leader for the teacher, school staff, students, parents, and environments. The act of the leader will be affecting the one who is led, human being tends to imitate those who they consider to be better than them. ${ }^{12}$ All of those competences and leadership characteristic of the principal is necessary to lead the school to achieve its target. The interaction between the principal and the teachers become the main points to be considered for the school's condition. ${ }^{13}$

To simplify matter, the principal can be called as the brain of the body. It cannot do everything without the other part of the body. However, brain is the

${ }^{7}$ Muhammad Sholeh, "Kefektifan Peran Kepala Sekolah dalam Meningkatkan Kinerja Guru." Jurnal Dinamika Manajemen Pendidikan. 1, No. 1, (2016): 41-54.

8 Rosdina, Murniati, and Yusrizal, "Perilaku Kepemimpinan Kepala Sekola dalam Peningkatan Kinerja Guru pada SD Negeri 2 Lambheu Kabupaten Aceh Besar," Jurnal Administratsi Pendidikan Pasca Sarjana Universitas Syiah Kuala. 3, No. 2, (2015): 69-78.

${ }^{9}$ Kodiran, “Kepala Sekolah Sebagai Tugas Tambahan," Al-Idarah:Jurnal Kependidikan Islam 8 , No. 1, (2017): 146-158.

${ }^{10}$ Sholeh, Muhammad. (2016). Kefektifan Peran Kepala Sekolah dalam Meningkatkan Kinerja Guru. Jurnal Dinamika Manajemen Pendidikan. Vol. 1, No. 1, (pp. 41-54)

${ }^{11}$ Ibid

12 Rosdina, Murniati, and Yusrizal, "Perilaku Kepemimpinan Kepala Sekola dalam Peningkatan Kinerja Guru pada SD Negeri 2 Lambheu Kabupaten Aceh Besar," Jurnal Administratsi Pendidikan Pasca Sarjana Universitas Syiah Kuala. 3, No. 2, (2015): 69-78.

${ }^{13}$ Kodiran, "Kepala Sekolah Sebagai Tugas Tambahan," Al-Idarah: Jurnal Kependidikan Islam 8, No. 1, (2017): 146-158. 
only part of the body that can manage the other part to move into one direction. To have a good body, the good brain is necessary.

\section{Organizational Communication.}

To ensure that every individual in a school able to work together to achieve the expected goals is an unavoidable ability to have by the principal. In this case, a principal is required to not only have vision for the school, but also lead everyone to go through the right path and achieve the vision. In most cases show that an effective communicational organization will create a condusive and effective organization's athmosphere. ${ }^{14}$

The prominence aspect in organizational communication is the deliverance of values and targets. Organizational communication's indicator is the occurrence of two-way communication, between the communicator and communicant. The communication's form between those two elements is what called as the organizational communication. ${ }^{15}$ If the organizational communication is better, then the comfortability and a suitable atmosphere will have bigger possibility to be created in an organization. Those conditions will lead to the trust and loyalty of teachers and education staffs. ${ }^{16}$

In organizational communication there are four types of communication, those are upward, downward, horizontal and external communication. ${ }^{17}$ An upward communication is a type of communication that derives from the leader to all members. The second type is downward communication. It works oppositely from downward communication; it goes from lower level to the upper level. On the other hand, the complexity of an organization will lead to the third form of communication; horizontal communication. Horizontal communication is conducted in form of coordination between units or members. The last one is external communication. This type of communication is commonly applied by organizations. As communication is conducted between the organization with other people or community from outside, such as the stakeholders or government. At the end, the main point is the deliverance of the message between unit or member to the other, whether inside or outside the organization.

${ }^{14}$ A. Ismail et. al. "Effect of Managers' Communication on Training Application with Motivation to Learn as Intervening Variable," The South East Asian Journal Management 12, No. 2, (2018): 123-143.

15 Muhammad Najih Farihanto, "Komunikasi Organisasi dalam Penanaman Budaya Organisasi di Seminari Tinggi Santo Paulus Yogyakarta," Jurnal Ilmu Komunikasi 10, No. 2, (2013): 179-194.

${ }^{16}$ Siti Azizah, "The Roles of Communication and Organizational Culture in Maintaining Employees' Loyalty," Jurnal Ilmu Komunikasi 8, No. 1, (2011): 49-59.

${ }^{17}$ Fred C. Lunenburg, "Formal Communication Channels: Upward, Downward, Horizontal and External," Focus on College, Universities, and Schools 4, No. 1, (2010): 1-7. 
An organization, including educational organization such as school, should have value and vision. Those two things need to be delivered appropriately. The communicative message deliverance correlates positively to the success of a school. The reason behind it is the positive correlation between organizational communication and organizational culture.

The situation is created because of the existence of positive correlation between organizational communication and organizational culture. Both communication and culture of an organization is affecting and correlating one another. ${ }^{18}$ If the organizational communication is good, the same goes to the organization culture.

\section{Reward}

Teachers and educational staffs are the prominent elements in an educational institution. For an educational institution, teachers and educational staffs are irreplaceable main resources..$^{19}$ In this case, it is important to highlight the important paradigm in education, an educational institution will not be able to survive and work efficiently if the man power, teachers and staffs, not giving their hundred percent effort for the institution. There are some prominent aspects to be noted in order to maximalize the quality of the human resources in an educational institution, one of them is giving stimulus like rewards and appreciation. Regarding to the fact that rewarding has a positive correlation with employee's motivation. ${ }^{20}$

There three important points regarding the function of reward in an organization; (1) be the main attractor for the fresh new human resources. (2) Improving the performances of the institution. (3) Improving commitment and loyalty of the workers. ${ }^{21}$ From the three points above there are two important effects from the rewarding, the first one is the contiuous regeneration of the qualified human resources and the improvement of the human resources of an institution, including an educational institution.

${ }^{18}$ Siti Azizah, "The Roles of Communication and Organizational Culture in Maintaining Employees' Loyalty," Jurnal Ilmu Komunikasi 8, No. 1, (2011): 49-59.

19 Ayesha Binte Safiullah, "Impact of Reward on Employee Motivation of Telecommunication Industry of Bangladesh: An Empirical Study," IOSR Journal of Business Management 16, No.2, (2014): 22-30.

${ }^{20}$ Vera Akafo and Peter Agyekum Boateng, "Impact of Reward and Recognition on Job Satisfcation and Motivation," European Journal of Business and Management 7, No. 24, (2015): 112-124.

21 Daniel Njoya Ndungu, "The Effects of Rewards and Recognition on Employee Performances in Public Educational Institutions: A Case of Kenyatta University, Kenya," Global Journal of Management and Business Research: A Administration and Management. 17, No. 1, (2017): 4368 
From a general point view, reward is classified into two, intrinsic reward and extrinsic reward. Intrinsic reward is completion, achievement, autonomy and personal growth. While extrinsic reward is financial, intrapersonal, and promotion. ${ }^{22}$ It should be noted, reward in an institution, including educational institution, is not only in form of financial or promotion. Appreciation of works, freedom of speech and training facility given by the company are also part of reward for the employee. These are important as consideration for someone to join a company, financial and position are not the only considerations, seeing themselves as person with a great potential to be improved are also part of the considerations.

To conclude the idea related with rewarding, it is possible to state that reward in an organization or institution is a necessary price to achieve the success. Especially in this era, where the competition between educational institutions is getting tighter, especially human resources.

\section{Research Methodology}

The research focusing in the school leadership in Al-Azhar Mandiri Palu Junior High School, Central Sulawesi which led by Drs. Abdul Basit Arsyad, M.Pd. In this research there are two main aspects that become the focuses of the school leadership in running the school organization, those are organizational communication and rewarding that implementing in SMP Al-Azhar Mandiri Palu.

This research used qualitative method and under the design of case study research. There are three instruments used in data collecting techniques, those are in-depth interview, observation, and documents. Interview be the primary instrument and strengthen by the secondary instruments, observation and documents from SMP Al-Azhar Mandiri Palu. The interview was conducted with the principal, vice principal, school's treasurer, teachers and students of SMP AlAzhar Mandiri Palu. The source of document was taken school's documents such as school's rules, curriculum, organization chart, and others supportive documents like news, clipping, articles and others. The last, observation was done in order to see school's activity and condition.

In order to validate the data finding, the data were checked through data triangulation. Data triangulation was conducted by doing deep data analyzing with several correspondent to have proper data saturation. ${ }^{23}$ Data analysis was conducted with two steps process, the first one is general data analyzing. The

22 Yohanes Andhi Kurniawan, "Kepemimpinan Kepala Sekolah," Jurnal Manejemen Pendidikan 9, No. 1, (2018): 61-70.

${ }^{23}$ John W. Cresswell, Research Design Qualitative, Quantitative, and Mixed Methods Approaches. (Thousand Oaks: SAGE Publications, Ink. 2014) 
second is data analysis based on the research design. ${ }^{24}$ The second step of data analysis was done by analyzing through the research theme.

\section{Research Result}

General Pictures of Junior High School Al-Azhar Mandiri Palu

SMP Al-Azhar Mandiri Palu is one of the favorite schools in Central Sulawesi. The school was established since 1992 with its principal and founder Drs. Abdul Basit Arsyad, M.Pd. At the first year of its establishment, SMP Al-Azhar Mandiri Palu could be classified as a school which was not so popular. At its first year, there were 40 students who enrolled in SMP Al-Azhar Mandiri Palu and after the first three-years there were only 24 students that graduated as the first graduation. This condition was caused by the discipline and values that strongly applied in SMP Al-Azhar Mandiri Palu, even since the first year.

The long-lasting and tiredless effort of Al-Azhar Mandiri Palu show better results from time to time. In 2007 Al-Azhar Mandiri Palu Junior High School got "A" grade for its accreditation from the government, The Department of Education and Culture. The two years later, in 2009, it was given new status as the RSBI or Pilot for International Standard School. A status that given for school that has a good qualification and prepare to have international standard in their teaching and learning process. Their grade become better, in 2016 the government classified Al-Azhar Mandiri Palu as an "Integrated School", because can have high national examination's score result for 5 years in a row and also the best school in Sulawesi.

Besides its accreditation and appreciation from the government, SMP AlAzhar Mandiri Palu has achieved plenty of succeses. For more than two decades, SMP Al-Azhar Mandiri Palu has achieved various achievements from local up to international level. Every year it able to send delegation for national events, such as National Science Olympiad (OSN) and English Debate Competition. Not only for academical success, SMP Al-Azhar Mandiri Palu has written its name for its success in non-academic subjects, such as art and sports competition. The result is obvious, the level of acceptance of SMP Al-Azhar Mandiri Palu among the people is rising. It is shown by the number of students that enroll to the school every year, in which the number could reach more than twice the number of the seats prepared by the school.

Besides all of the achievement and appreciation given, SMP Al-Azhar Mandiri Palu also known for its quality in term of implementing religious value in its daily activity and rules. The interesting part of this full-day school is that the

\section{${ }^{24} \mathrm{Ibid}$}


school itself is not an Islamic school. As stated by the headmaster and founder of SMP Al-Azhar Mandiri Palu, Drs. Abdul Basit Arsyad, M.Pd. "SMP Al-Azhar Mandiri Palu is not an Islamic school, but implementing Islamic value in its daily activity." 25 It status as a non-Islamic school is proved by the open-mindedness and inclusivity of SMP Al-Azhar Mandiri Palu in hiring teachers and staffs or accepting students from various religious background. On the other hand, in its daily activity Islamic value is well-implemented in SMP Al-Azhar Mandiri Palu, activities like jama'ah praying, boarding activity in Ramadhan, celebrating Prophet's Birth Day or Maulid Nabi, Islamic New Years ( $1^{\text {st }}$ of Muharram) become routines for Al-Azhar Mandiri Palu. Its rule also obligates Moslem students, teachers and staffs to wear hijab as their uniform. Students who learn Qur'an and be hafidz is quite easy to be found in Al-Azhar Mandiri Palu and some of them become the delegation for Islamic knowledge competition. The school even accommodate students who wants to improve their knowledge about Islam with activities.

\section{Organizational Communication SMP Al-Azhar Mandiri Palu.}

Hartley explained that an interpersonal communication is a two-wat communication. ${ }^{26}$ Starting from that point, it is clear for us that communication is not only giving order, but also to make sure there is a lively communication between the communicator and communicant. In SMP Al-Azhar Mandiri Palu, the leader of the school enhances the leadership with openness and communicative circumstances. That the first communication has been started since the jobinterview of the teachers or the staff.

In its implementation, organizational communication in SMP Al-Azhar Mandiri Palu not only conducted in form of upward communication, but also downward and horizontal communication. One of the main sources of how the organizational communication implemented in SMP Al-Azhar Mandiri Palu is the organigram of the school which is designed based on the needs of the school management.

The head of SMP Al-Azhar Mandiri Palu always implementing an openness of communication with teachers and staffs, it also supported by the continual meeting and the use of technological insturments in order to ensure that the system of SMP Al-Azhar Mandiri Palu runs according to the rules. As explained by the school's treasurer, Mr. Fuad Syakir, M.Pd. "Mr. Basit (the principal) always reminds teachers and staffs to activate their mobile phone." ${ }^{27}$ That thing is done

\footnotetext{
${ }^{25}$ Interview with JSH Al-Azhar Mandiri Palu's Principal, Drs. Abdul Basit Arsyad, April 2019

${ }^{26}$ Peter Hartley, Interpersonal Communication, (Padstow: T.J. Press, Ltd., 1996).

${ }^{27}$ Interview with JSH Al-Azhar Mandiri Palu's Principal, Drs. Abdul Basit Arsyad, April 2019
} 
by the principal in order to ensure the easiness and effectiveness of communication among the school's members.

Not only has the downward communication, SMP Al-Azhar Mandiri Palu also has a good upward communication athmosphere. Teachers and staffs in SMP Al-Azhar Mandiri Palu can express ther ideas and innovation to the principal in an accommodative way. It also quite common to see students give their opinions to the school's in order to improve the quality of the schools. As stated by the leader of OSIS (Students Organization) of SMP Al-Azhar Mandiri Palu, Hidaftiyah Nurintan Lingga Ninggrum Harmain. "Ideas (from the students) can be (applied) will be implemented." 28

Beside a good coordination, either through formal occasion and meeting or informal one, communication and inclusivity among individuals in Al-Azhar Mandiri Palu is much appreciated. Among the way to strengthen the bond between the individuals in SMP Al-Azhar Mandiri Palu, annual family gathering is a unique event. The family gathering is held every year by the institution in which all the teachers and staffs, including their family members joins. To ensure the participation, institution obligate the participants to join the event.

Not only strengthen the bound between the individuals in Al-Azhar Mandiri Palu, the school also obligate the teachers to be able to have a warm and cooperative communication with parents. To ensure this condition, every morning the teachers greet the parents who take their sons or daughters to the school. It is done in schedule to let all teachers have their moments to make a good relationship and athomosphere with the parents. Beside it also done to build a comfortable and trust from parents to the school.

SMP Al-Azhar Mandiri Palu also innovates continually, including the use of communicational technology. The school made a mobile application for parents, so the school can keep in touch with the parents and continually supply the latest information related with their children or the school. Al-Azhar Mandiri Palu also support the access information for public through several online platforms, such as school's website and social media.

The importance of communication becomes one of the main focuses of AlAzhar Mandiri Palu Junior High School, therefore in running the school, the principal continually improving the quality of communication in a proportional and effective way. The atmoshphere, circumstances, regulation, and technology are some aspects that used by the school to improve their communication process. Under the supervision and guidance of the principal with cooperation of teachers, staffs, parents, students and social environment.

${ }^{28}$ Interview with JSH Al-Azhar Mandiri Palu's Students Organisation Leader, Ninggrum Harmain, April 2019 
Rewarding of SMP Al-Azhar Mandiri Palu.

Base on it main function, reward's actual purpose is to attract a new and fresh human resources, improving performances, and maintin the loyalty and commitment of individuals. ${ }^{29}$ Therefore, able to rewarding employee efficiently is a prominent aspect to be had by a principal, especially following the principal's functions as a figure that had to ensure every indivduals able to work together and do their best contribution for the school.

In SMP Al-Azhar Mandiri Palu, the principal appreciating individuals without any exceptional. Appreciation and reward which are given to the teachers and staffs, not only intrinsically, but also extrinsically.

Extrinsic rewards which are applying in the school is conducted in several forms, the main reward is an appreciative fees and welfare. The idea derives from the principal's principle that someone's performance cannot be motivated only by their willingness and passion in working, their financial welfare should also be guaranteed. The school provides various allowance, starts from salary up to bonuses, including insurances. One of the special treatments given by Al-Azhar Mandiri Palu is their appreciation for the teachers and staffs' loyalty. Despite being a private school, Al-Azhar Mandiri Palu always gives financial and allowance to those who are not active in school anymore or even already pass away. It is proven by how Al-Azhar Mandiri Palu regulary visit the teacher's family to give goods and money, despite the teacher had already passed away for years. The school also provides their own self insurance that prepare for teachers and their family in an emergency situation and need to be treated quickly.

Besides the financial and allowance given by the school of the teachers, SMP Al-Azhar Mandiri Palu also implemented transparent and objective system. In other word, everyone has the same chances to be promoted. As stated by Mr. Arafat Arsyad, S.I.P. "(Promotion) is given based on the quality, creativity." 30 (Interview, April 2019).

Objectivity is a prominent aspect in giving promotion for the employee. The observation of someone's quality has begun since the first time they be part of the school. How the teachers can adapt with the school's environment and exploring themselves in SMP Al-Azhar Mandiri Palu be the main indicators. Therefore, in giving a reward in the form promotion, everyone is treated fair,

29 Daniel Njoya Ndungu, "The Effects of Rewards and Recognition on Employee Performances in Public Educational Institutions: A Case of Kenyatta University, Kenya," Global Journal of Management and Business Research: A Administration and Management. 17, No. 1, (2017): 4368

30 Interview with JSH Al-Azhar Mandiri Palu's Teacher, Arafat Arsyad, S.I.P, April 2019 
proportional and objective. Every individual in Al-Azhar Mandiri Palu has the same chances and opportunity, everything is based on quality.

Besides the extrinsic rewards, SMP Al-Azhar Mandiri Palu also apply an intrinsic form of reward proportianlly and fairly. Among the most visual intrinsic reward given by the school is the autonomy for the teacher to explore their creativity in working. Teachers and staffs in SMP Al-Azhar Mandiri Palu has big chances to innovate and exploring ideas in their working.

In Al-Azhar Mandiri Palu, it is common for the school to give full support and protection related with good program or regulation. Therefore, the teachers, staffs, and even the students are doing one hundred percent in contributing for school. On the other hand, the principal does not do any intervention that dictating and lessen the creativity.

There other form of reward that also given by SMP Al-Azhar mandiri Palu for the individuals, based on their achievement and qualification. Just like the other rewards, students also have the same chances to explore themselves based on their achievements, academically or non-academically. One of the forms of the reward provided by the principals is the facility. As an example, is the paintingwall that made by the school as the facility for the students are good in painting and want to explore and improve their ability. The unique thing, the painting-wall are put just next to the principal's office. It is a proof that school supporting students who have talent in painting and contributing to school with their talent.

As for teachers, SMP Al-Azhar Mandiri Palu also ensure its teachers to have equality in quality and continual skills improvement. Therefore, it is not only giving appreciation for those who already good in teaching or working, but also improving from good to better. One of the school's innovations is by establishing and implementing PUTI GUNA (Teachers Training Center). The school adopting the program from the government program and also adapting it based on the school needs. The program becomes one of the main programs provided by the school to improve their teachers' quality. All the teachers who applied and accepted by the school have to join the PUTI GUNA.

Besides the PUTI GUNA, the school also consistenly do trainings or inviting experts from various places to improve the performance and quality of the teachers of SMP Al-Azhar Mandiri Palu.

Islamic Value

JHS Al-Azhar Mandiri Palu is one of the most favorite school in Palu, its consistency in education lead to numerous achievements. In the other hand the 
school's members, students and teachers, is well-known for having good attitude and politeness. With the motto "Cerdas Berakhlak", Al-Azhar Mandiri Palu shows that intellectual, emotional and spiritual should be in balance.

Despite their implementation of Islamic characteristic JHS Al-Azhar Mandiri Palu is not an Islamic school. Clearly state by the school's management that Al-Azhar Mandiri Palu is not an Islamic school, however the Islamic value implemented very well in the school. In fact, Al-Azhar Mandiri Palu frequently achieves achievements in Islamic field, such as tahfidz.

The characteristic of Islam in Al-Azhar Mandiri Palu is not only shown by plenty of achievements, but also moderate character that shown by school management. JHS Al-Azhar Mandiri Palu openly accept students and teachers from various background, either Muslim or non-Muslim. For non-Muslim students, JSH Al-Azhar Mandiri Palu event lifted up some rules and obligations in order to respect the differences. In the other hand, Al-Azhar Mandiri Palu also hold their religious principle strongly. As stated by the Principal, that they allowed teachers from different Islamic understanding, mazhab or Islamic mass organization background, however they are not allowed to spread their understanding to the students as it is the job of Islamic teachers who is considered to master the field.

From this standing ground, there is a big question of how Al-Azhar Mandiri Palu able to implement the Islamic value when they are not an Islamic school. There are several reasons of the condition, including of the consistency and the good examples shown by the schools' teacher and management. Al-Azhar Mandiri Palu since its establishment has held its values without changing, the motto "cerdas berakhlak" is not only a motto, but also a value that has been implemented for decades. The teachers and managements also oftenly take big part in religious events and matters in Palu and Central Sulawesi. These conditions make the value could easily implemented, even the values mostly come from the students own understanding of how to behave and spiritually well.

Al-Azhar Mandiri Palu becomes one of the proofs, how good management system and consistency of quality lead to the real and positive changes. Especially in education where to point is not only to create a good understanding, but the changes of human being into a better individual.

\section{Conclusion}

The communication that build by the leader or principal in an educational institution has prominent role to ensure the establishment of good teamwork and 
coordination in the educational institution. SMP Al-Azhar Mandiri Palu has applied and implemented an effective communication system to ensure the establishment of an organizational quality with its goal, to have a good educational institution. Communication model, such as downward communiation has implemented soundly by the principal. In which the principal manages to communicate with his fellow teachers and employee. The teachers and staffs also perform an effective upward communication. In which the teachers able to communicate their opinion and idea following a proper organizational coordination. The similar condition also implemented in the school's horizontal and external communication. The organizational communications habits in the school also provided with the support of technology and regulations that can improve the quality and stability of the communication.

The reward system that applied in SMP Al-Azhar Mandiri Palu, either for the teachers, educational staffs, and the students is runs well and proportionally maintain. Facilty and allowance are given as the appreciation and reward from the school based on the capacity and performances. The placement and promotion also given fairly and objectively, based on someone's quality and capability, in which everybody has the same chances. Besides the intrinsic form rewards, extrinsic rewards are also given by the school. Some of the most important aspects of the extrinsic rewards by the school are the facilities and programs that provided by the schools in order to improve the quality for the teachers or students, especially those who have shown good potential. For teachers, the schools also provide training center or programs, such as PUTI GUNA or sending and facilitating teachers to join skill's improvement programs outside the schools.

Rewards and communications that are manage effectively by the principal have motivated the teachers and educational staffs in which resulting in their loyalty for the institution. It is proven by the numbers of teachers that rejected other job's offer given by other schools or companies, the number even reaches $90 \%$ of the teachers. Besides loyalty, value and work principles have been inducted to all teachers, staffs, and students. In which they teach, learn, and work in a very discipline and integrating manner as it is the main core of SMP Al-Azhar Mandiri Palu.

The result also become clear in how Al-Azhar Mandiri Palu able to implementing the Islamic value with the main goal to changes the character of people. Consistency of good management results in the quality of the education itself. Students's characters and numerous achievements are part of the proof of how good Islamic value implemented in a non-Islamic school. This kind of success is not a simple thing to achieve, but for a long struggle in decades.

The research, especially for educational institution, has shown that the principal should be able to create a condusive and comfortable atmosphere for the teachers and educational staffs in the school. It is very important, especially 
reflected to the role of the principal as the leader the school who has to be able to lead all the members and manage the resources effectively in order to achieve the goals of the schools.

For the researcher, especially educational management researcher, a broader exploration regarding schoos' principal is necessary to improve the educational condition in Indonesia. This condition also refers to our social diversity in which will lead to the various leading system.

\section{References}

Ahmad, Syarwani. (2013). Faktor Penentu Keberhasilan Kepala Sekolah. Jurnal Penelitian dan Evaluasi Pendidikan. Vol. 17, No. 1, (pp.127-147).

Akafo, Vera \& Boateng, Peter Agyekum. (2015). Impact of Reward and Recognition on Job Satisfcation and Motivation. European Journal of Business and Management. Vol. 7, No. 24, (pp.112-124)

Azizah, Siti. (2011). The Roles of Communication and Organizational Culture in Maintaining Employees' Loyalty. Jurnal Ilmu Komunikasi. Vol. 8, No. 1, (pp.49-59).

Cresswell, John W. (2014). Research Design Qualitative, Quantitative, and Mixed Methods Approaches. Thousand Oaks: SAGE Publications, Inc.

Farihanto, Muhammad Najih. (2013). Komunikasi Organisasi dalam Penanaman Budaya Organisasi di Seminari Tinggi Santo Paulus Yogyakarta. Jurnal Ilmu Komunikasi. Vol. 10, No. 2, (pp.179-194).

Hartley, Peter. (1996). Interpersonal Communication. Padstow: T.J. Press, Ltd.

Hutagalung, Inge \& Ritonga, Rajab. (2018). Pengaruh Iklim Komunikasi dan Komitmen Organisasi terhadap Kepuasan Kerja Pegawai Kecamatan XYZ Bekasi. Jurnal Kajian Komunikasi. Vol. 6, No. 2, (pp.72-84).

Ismail, A., Rendika, N., Santoso, A.S., Foboy, N.A., \& Nor, A.M. (2018). Effect of Managers' Communication on Training Application with Motivation to Learn as Intervening Variable. The South East Asian Journal Management. Vol. 12, No. 2, (pp.123-143).

Kementerian Pendidikan dan Kebudayaan RI, 2017, Panduan Kerja Kepala Sekolah, Jakarta: Direktorat Pembinaan Tenaga Kependidikan.

Kodiran. (2017). Kepala Sekolah Sebagai Tugas Tambahan. Al-Idarah: Jurnal Kependidikan Islam. Vol. 8, No. 1, (pp. 146-158)

Kurniawan, Yohanes Andhi. (2018). Kepemimpinan Kepala Sekolah. Jurnal Manejemen Pendidikan. Vol. 9, No. 1, (pp.61-70). 
Lunenburg, Fred C. (2010). Formal Communication Channels: Upward, Downward, Horizontal and External. Focus on College, Universities, and Schools. Vol. 4, No. $1,(\mathrm{pp} .1-7)$

Ndungu, Daniel Njoya. (2017). The Effects of Rewards and Recognition on Employee Performances in Public Educational Institutions: A Case of Kenyatta University, Kenya. Global Journal of Management and Business Research: A Administration and Management. Vol. 17, No. 1, (pp.43-68)

Rosdina, Murniati, \& Yusrizal. (2015). Perilaku Kepemimpinan Kepala Sekola dalam Peningkatan Kinerja Guru pada SD Negeri 2 Lambheu Kabupaten Aceh Besar. Jurnal Administratsi Pendidikan Pasca Sarjana Universitas Syiah Kuala. Vol. 3, No. 2, (pp. 69-78)

Safiullah, Ayesha Binte. (2014). Impact of Reward on Employee Motivation of Telecommunication Industry of Bangladesh: An Empirical Study. IOSR Journal of Business Management. Vol.16, No.2, (pp.22-30)

Sholeh, Muhammad. (2016). Kefektifan Peran Kepala Sekolah dalam Meningkatkan Kinerja Guru. Jurnal Dinamika Manajemen Pendidikan. Vol. 1, No. 1, (pp. 41-54) 